\title{
The effects of L1 use and dialogic instruction on EFL writing
}

\author{
Ayfer Tanışa* (D), Feyza Harman Şensoyb (D), Derin Atayc (iD \\ a Kırklareli University, Kırklareli, 39000, Turkey \\ ${ }_{b}$ King's College London, London, WC2B 4BG, United Kingdom \\ c Bahçeşehir University, İstanbul, 34353, Turkey \\ Received 18 February 2019 | Received in revised form 12 May 2019 | Accepted 19 June 2019
}

\author{
APA Citation: \\ Tanış, A., Harman Şensoy, F., \& Atay, D. (2020). The effects of L1 use and dialogic instruction on EFL writing. \\ Eurasian Journal of Applied Linguistics, 6(1), 1-21. \\ Doi: 10.32601/ejal.710178
}

\begin{abstract}
This paper investigates the effects of three different types of prewriting instruction on Turkish students' L2 writing production capabilities. This mixed method study was carried out with 45 Turkish EFL students enrolled at a state university. Students were allocated into three groups randomly. In the control group the prewriting phase was carried out with monologic instruction in L2, while in one of the experimental groups, it was done with dialogic instruction in L2 and in the second experimental group, dialogic instruction was conducted in L1. Data were collected by means of pre-and post-writing tasks of the students and semi-structured interviews, and analyzed with Kruskal-Wallis and Mann Whitney tests and through pattern coding, respectively. The statistical results indicated that the group who used their L1 during pre-writing stage with the help of dialogic instruction had higher mean scores than the group who was instructed monologically and the group who was instructed through dialogic instruction in L2.

(C) 2020 EJAL \& the Authors. Published by Eurasian Journal of Applied Linguistics (EJAL). This is an open-access article distributed under the terms and conditions of the Creative Commons Attribution license (CC BY-NC-ND) (http://creativecommons.org/licenses/by-nc-nd/4.0/).
\end{abstract}

Keywords: Dialogic instruction; EFL writing; L1; L2.

\section{Introduction}

Developing learners' writing skills in L2 has been a concern in tertiary education for a long time (Jordan, 1997). Writing is a complex, meaning-making, cognitive phenomenon in which multiple factors are at play (Byrnes \& Manchón, 2014). Thus, the requirements for successful writing are often difficult to meet for many students in their L1 (Bereiter \& Scardamalia, 1987; Graham \& Perin, 2007), and the task becomes much more complex and demanding for those who have to write in a foreign language and who are additionally expected to cope with the institutions' literacy expectations.

Writing plays a significant role in promoting language learning and development because of the problem solving nature of writing itself and the attention paid by

\footnotetext{
* Corresponding author. Tel.: +090-507-841-96-88

E-mail address: ayfertanis@gmail.com

http://dx.doi.org/10.32601/ejal.710178
} 
learners to language use and processing (Byrnes \& Manchón, 2014). In Turkey, writing in English for academic purposes is a skill to be acquired in undergraduate programs; however, research conducted on L2 writing, though few in number, revealed that Turkish language learners find writing to be the most difficult language skills to master (Abdel Latif, 2007; Kurt \& Atay, 2007; Sağlam, 1993). Many Turkish students regardless of their L2 proficiency, feel under "stress" about not being able to "think of anything" or "generate ideas" on the given topic. Working as English instructors for years, we have realized that low writing performance of the Turkish EFL students is beyond their L2 proficiency, which, according to Ortega (2012), is a need yet "not a sufficient condition" (p.412) for the development of L2 writing. Thus, we believed that a structured planning stage inducing active student participation and engagement would improve students' L2 writing skills. Thus, our aim in the present study was to explore if there was any improvement in the L2 writing performance of EFL students as they were engaged in a structured pre-writing tasks based on dialogic instruction (DI) in L2 and L1.

\subsection{Pre-writing instruction}

Planning, or pre-writing stage is considered to play a major part in the writing process, (Bereiter \& Scardamalia, 1987; Caccamise, 1987; Levy \& Ransdell, 1995). It is during this initial stage when learners are expected to set goals for the writing task, originate ideas in relation to these goals and arrange them to facilitate action, translate and make the writing production easier (Hyland, 2003; Williams, 2005). As suggested in Kellogg's model of writing process (1996), formulation entails planning, and the writers try to retrieve ideas and knowledge to build a new text and linguistic elements through planning stage.

Teachers also try to elicit opinions through different strategies and techniques such as concept mapping (Ojima, 2006; Ruddell \& Boyle, 1989), writing a story based on a picture (Ghavamnia, Tavakoli, \& Esteki, 2013), outlining (Kellogg, 1988), clustering (Becker, 1991), dialogue journals (Urzua, 1987), brainstorming (Scott, 1996; Sebranek, Meyer, \& Kemper, 2000; Williams, 2005), categorizing ideas and class discussions (Martinez-Gibson, 1998), dyads and triads (Freeman \& Freeman, 2001), free writing (Vacca, Vacca, \& Mraz, 2010; Williams, 2005), drawing (Byrd, 2011), graphic organizers (Novak, 1998), four column charts (Auman,1999), and L1 use for planning (Akyel, 1994; Beare, 2000; Friedlander, 1990; Krapels, 1990; Sevgi, 2016; Wang, 2003). Pre-writing techniques necessitate students' active involvement, which is found to facilitate their L2 writing skills (Hornung, 2000; Rau \& Sebrechts, 1996). Students make personal connections and review vocabulary necessary to complete the final product more communicatively and successfully (Byrd, 2011; Kramsch, 1993; Strasma \& Foster, 1992). In that sense, pre-writing activities help them either activate existing schemata or create new input for vocabulary, syntax and cultural content for the writing task (Carrell \& Eisterhold, 1983; Kroll, 1990; Swaffar, 1988). Thus, in the present study we adopted DI as pre-writing strategy and examined its potential for improving learners L2 writing. 


\subsection{Dialogic versus monologic instruction in L2 writing}

The theoretical foundation of DI arises from the work of Bakhtin (1984), who, by demonstrating how the voices of other people get interwoven into what we say write and think, suggests that a person's thinking and knowing occurs in and through dialogic speech (Teo, 2016).

In the last years, DI has been extensively characterized as a pedagogical approach that engages learners in the cooperative creation of meaning and can be enacted through a range of possible talk strategies in the classroom setting (Alexander, 2006; Gregory, 2007; Webb, Franke, Ing, Wong, Fernandez, Shin, \& Turrou, 2014; Wells, 2000). DI opens the space for students to question the ideas and opinions from their peers, teachers or textbooks so there is greater construction of knowledge. There are some key distinguishing characteristics that appear in dialogic classrooms (Mercer \& Littleton, 2007; Scott, Mortimer, \& Aguiar, 2006). Responsibility for the content of talk is shared by the individuals within a group and they ask questions in turn and evaluate each other's answers (Splitter \& Sharp, 1995). There is an "ongoing communicative interchange that acknowledges differences in knowledge, experience or ability without reifying them" (Burbules, 1993, p.34). Pimentel and McNeill (2013) claim that expressing a thought with reasoning, formulating ideas and elaborated explanations on the student talk can reflect dialogic discourse. DI is totally in contrast with monologic instruction (MI) in which knowledge is transmitted unilaterally from teacher or textbook to students (Alexander, 2008; Galton, 2007). Such instruction still dominates classroom practice in many parts of the world (Alexander, 2006; Burns \& Myhill, 2004; Kumpulainen \& Lipponen, 2010; Parker \& Hurry, 2007) and research conducted in Turkey also demonstrates that despite national strategies to promote more interactive approaches to L2 teaching and learning, traditional, teachercentered monologic practices are still widely adopted and that teachers remain strictly in control of class talk (Altinyelken, 2011; Hatipoglu Kavanoz, 2006).

A major reason for selecting DI is that it is recognized to be effective in improving students' higher order thinking skills (Murphy, Wilkinson, Soter, Hennessey, \& Alexander, 2008; Schwarz, Neuman, \& Biezuner, 2000; Wegerif, Mercer, \& Dawes, 1999), questioning skills (Reznitskaya, Kuo, Clark, Miller, Jadallah, Anderson, \& Nguyen-Jahiel, 2009) and ultimately idea generation capabilities (Sedova, Sedlacek, \& Svaricek, 2016) during L2 writing process.

A number of studies conducted on DI in L1 settings in primary (Mercer, Dawes, \& Staarman, 2009), secondary (Gillies, 2016; Otten, Engledowl, \& Spain, 2015) and in tertiary education (Hajhosseiny, 2012) on various subjects, generally in science and maths, have shown that when teachers make regular use of certain dialogue strategies, students' participation in class and their educational outcomes are likely to benefit (Mercer \& Dawes, 2014, p.439).

Additionally, some of the researchers have investigated the role of dialogic interactions through journals and the results of these studies have revealed that 
learners have developed a sense of audience, voice and power in their writing process by means of these dialogue journals (Mahn, 2008; Peel, 2014; Urzua, 1987). As such, dialogue creates opportunities for students to enhance ideas through mutual shaping which are shared and open to learning both with and from the students (Han \& Hyland, 2015; Steward \& Mcclure, 2013). Motlhaka and Makalela (2016) also assert that the use of dialogic pedagogy as a strategy and L1 to generate ideas facilitate university students' L2 writing development that would not be possible in traditional, monologic academic teaching approaches as students construct their desired voices in writing through the use of compensation and social strategies by means of the dialogic instruction when they translanguage between L1 (Sesotho) and L2 writing (English).

Thus, we believe that regular use of DI in the planning stage of writing will facilitate meaningful interaction among learners and enable the teacher to respond to the diverse cultural educational and writing needs of students "clarifying meaning and resolving ambiguities" (Hyland \& Hyland, 2006, p. 8). DI will foster awareness in the students and progressive understanding to construct their desired voice in L2 writing (Motlhaka \& Makalela, 2016).

We also implement DI in L1 Turkish as an alternative in this study. In order to enhance the L2 writers' confidence in preplanning stage of writing, the students are encouraged to use their L1 to generate ideas associated with a topic, and to develop strategies that could facilitate their L2 writing development.

\subsection{L1 use in L2 writing}

A great deal of research has concentrated on the inclusion of mother tongue in L2 writing (Cohen \& Brooks-Carson, 2001; Wang \& Wen, 2002; Woodall, 2002) suggesting that the inclusion of L1 might be productive in the writing process for text generation (Cumming, 1989), L1 knowledge transfer to the target one (Edelsky, 1982; Friedlander, 1990), ideas and content development (Beare, 2000; Knutson, 2006; Lay, 1982; Wang, 2003; Whalen \& Mennard, 1995; Woodall, 2002), as well as task management, explanation and clarification (Akyel, 1994; Kim, 2010). However, there is a scarcity in the studies investigating the effects of DI and L1 integration in EFL classrooms.

Thus, the following research questions were addressed in this study:

1. Is there a statistically significant difference in the writing performances of students who are exposed to MI in L2, DI in L1 and DI in L2 in the planning stage of the writing lesson?

2. What are L2 learners' opinions about the use of MI in L2, DI in L1 and DI in L2 used in the planning stage?

\section{Method}

\subsection{Participants and setting}


The present study was conducted in the Academic English Writing I course given to freshman students at a Turkish state university. 45 Turkish EFL students, 20 female and 25 male with a mean age of 18.44, participated in this study. All groups, each with fifteen students, were taught by one of the researchers of this study, an experienced EFL instructor working at the institution for nine years. At the time of the study, the English proficiency of the participants was B1 level (CEFR) as obtained from the English proficiency test given by the institution.

At the beginning of the study, students in all three classes, randomly assigned as control and experimental groups, were asked to write an essay on their daily routines. A non-parametric test, Kruskall Wallis Test, revealed that there was not a statistically significant difference between the three classes regarding their L2 proficiency $\left(X^{2}=0.064, p=.968\right)$.

\subsection{Data collection and analysis}

Data obtained from the students' pre and post essays were analyzed through an analytic rubric developed by the testing office of the participants' university. Statistical analyses on the validity and reliability of the rubric were conducted by the testing office of the university. The rubric is composed of task achievement (35 points), vocabulary (20 points), grammar (20 points), cohesion- coherence (15 points), spelling (5 points) and punctuation (5 points), and is 100 points in total. The task achievement is evaluated separately for introduction paragraph (10 points), body paragraphs (15 points) and conclusion paragraph (10 points). 5 points are cut for each of the following: if there is no title, if there are two are or missing indents or if there is no hook for the introduction paragraph. The introduction paragraph was evaluated for the thesis statement, whether it controls the essay well and whether background information goes from general to specific relating to thesis well making the reader familiar enough with the topic. The body paragraphs were assessed in terms of effectively supporting the thesis statement, starting with an effective topic sentence, and whether the arguments and examples sufficiently support and explain the topic. The concluding paragraph was evaluated according to the clear and well-developed concluding sentence and comments, predictions or suggestions that are appropriate to the essay. The grammar section included whether structures are level appropriate and the ability in sentence formation. Similarly, the vocabulary section evaluated whether level and topic appropriate word choice or word use is available. Cohesioncoherence section assessed whether the essay expresses one definite main idea with no irrelevant sentences and it has a logical flow and progression of ideas with correct conjunctions and transition signals. Finally, correct punctuation, spelling and capitalization were also evaluated.

Each essay was graded by two EFL instructors of the same institution and the average scores of the raters were taken as the final score. The interrater reliability was found to be 0.93 for the pre-test and 0.96 for the post-test. The scores of participants in all three groups were analyzed by means of Statistical Packages for 
the Social Sciences (SPSS) through Kruskal-Wallis tests followed by Mann Whitney tests in order to find out whether there was a statistically significant difference between their writing scores. These nonparametric tests were chosen to measure and analyze performances of the groups as the number of the participants in each group was smaller than 30. However, since the number of analyses needed for a conclusion was higher, the chance of a Type I error increased.

Semi-structured interviews, lasting about 20 minutes, were conducted with 5 students randomly selected from each group to explore their perceptions regarding the type of pre-writing instruction they were exposed to. Turkish was used in the interviews. Students were informed about the audio-recording at the very beginning of the interview and asked to give informed consent. Interview data were analyzed by means of pattern coding, as suggested by Miles and Huberman (1994). For inter-rater reliability the semi-structured interviews and pre-and post-writing tasks were evaluated by both of the researchers. All of the students were informed about the research at the very beginning of the study and asked to give informed consent before taking part in the study.

\subsection{Procedure}

In all three groups, students were regularly assigned writing tasks on the same topics including their job future jobs, their favorite sports, their fears and ways of avoiding them, the importance of honesty, and lastly the reasons of immigration to other countries at the end of each week. We designed DI to be used in the experimental groups according to the DI principles of Sedova, Sedlacek and Svaricek (2016), and Smart and Marshall (2013). DI in our study was implemented during planning stage of the writing class and lasted for 15 minutes. The following four components suggested by Sedova et al. (2016) were implemented in a structured way.

(1)Student talk with reasoning: Students were encouraged to productively participate in the joint construction of knowledge, think and publicly present their thoughts (Ex.1).

\section{Excerpt 1 (taken from Lesson 4-Immigration)}

Teacher So, can you tell me why you think that these people in the picture immigrate?

Student It seems to me that they are very sad at first. Then I looked at the picture carefully and think they have to move their houses because of war. The wars caused them to leave their hometowns, their belongings, their families all behind. Poor countries are suffering as they cannot deal with powerful ones. Think about the Syrian people.

(2)Teachers' open questions of high cognitive demand: The instructor asked authentic questions with many possible answers that necessitated logical thought. Within DI, this type of question was regarded as a productive means of inducing dialogue. As the English level of the class was intermediate (B1) it was necessary to modify the cognitive demand accordingly. Thus, question level (from questions requiring lower-order thinking to ones requiring analysis); and question length (from 
focusing on correct answers to focusing on evidence and reasoning) changed gradually as the study went on, as suggested by Smart and Marshall (2013).

Ex 2 (taken from Lesson 5-Honesty)

Teacher So, can you tell me why you think that person telling a white lie for the sake of others is called a liar?

(3)Teacher uptake refers to situations in which the teacher built on what had been said by the student. (Ex 3)

Ex 3 (taken from Lesson 1-Future Jobs)

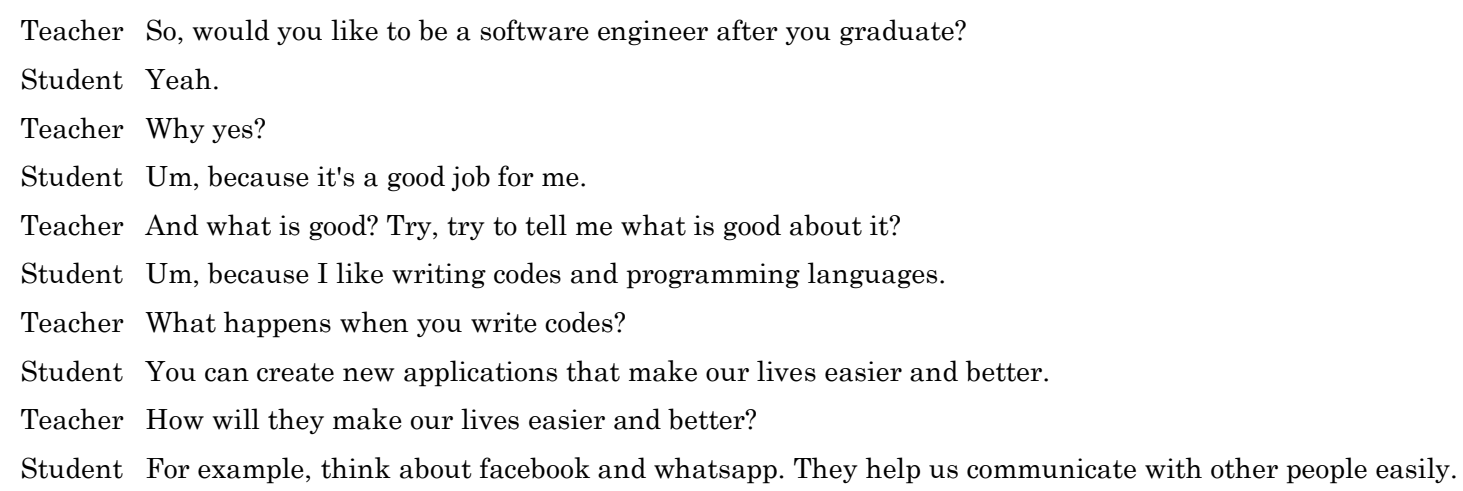

(4) Open discussion is one of the outstanding features that distinguish this method from the monologic method in the L2 pre-writing process. The teacher created an atmosphere and context for open discussion including a sequence that consisted of at least three or four participants who reacted to each other.

\section{Ex 4 (taken from Lesson 5-Honesty)}

\footnotetext{
Teacher Do you think all lies are wrong, or not? Why?

Student 1 I think some lies are OK as they make people happy. Does that make sense?

Student $2 \quad$ No.

Student $3 \quad$ I mean all lies aren't wrong, because it's not possible to tell the truth all of the time and people sometimes don't want to hear the truth and you may need to tell white lies not to make them sad.

Student $2 \quad$ Yeah, exactly.

Student $4 \quad$ But, I think a good person or good friend always tells the truth.

Student $1 \quad$ OK, for example when you ask a close friend to go to a football match. He doesn't want to. Do you prefer he says "I'm sorry. I cannot go. I am busy tomorrow." OR "No thanks. I don't really want to go."

Student $4 \quad$ But it depends.
}

In dialogic L1 group, not only the students but also the teacher switched codes back and forth in L1 and L2. 
On the other hand, MI in L2, used in the control group, was implemented with the dominance of teacher driven activities and traditional strategies. For instance, before writing an opinion essay about the importance of honesty, the teacher made use of a piece of a picture related to telling white lies to generate ideas on the given topic and raise students' background knowledge. After asking a few closed-ended questions, the teacher directly talked about the picture. The teacher sometimes made use of the same pre-writing materials and activities in the pre-writing stages of the lessons but differentiating the methods she applied in each group as indicated in Appendix A.

At the end of the study, semi-structured interviews (Appendix B) were conducted with five students from each group to have in-depth understanding with respect to the effects of the treatment on students' beliefs, feelings, and experiences in L2 writing skills.

\section{Results}

\subsection{Quantitative results}

Quantitative data of the research were obtained from the participants' writing scores. The statistical tests that were applied in the present study were KruskalWallis test, and Mann Whitney tests. The first research question concerns the effects of three different types of instruction on EFL learners' writing skills and whether L1 inclusion together with DI makes a change in students' writing performances.

The pre-test that was conducted at the beginning of the study indicated that there was not a statistically significant difference between the writing scores of monologic L2, dialogic L2 and dialogic L1 groups $\left(X^{2}=0.064, p=.968\right)$.

In order to understand whether the post-test scores of the three groups at the end of the study showed significant differences and to answer if the students' writing performances indicate any differences according to the type of treatment they received, a Kruskall Wallis test was applied.

Table 1. Kruskall Wallis test results comparing post-test scores

\begin{tabular}{llllll}
\hline Group & $N$ & Mean Rank & SD & $X^{2}$ & $P$ \\
\hline Monologic L2 & 15 & 10.13 & & & \\
Dialogic L2 & 15 & 24.90 & 2 & 25.174 & 0.000 \\
Dialogic L1 & 15 & 33.97 & & & \\
\hline
\end{tabular}

Table 1 shows the results of Kruskall Wallis post-test writing scores of students who were instructed with different methods for 5 weeks. The results of the analysis indicate that the post-test scores of the students differ significantly according to the instruction type that they received, $\left(\mathrm{X}^{2}=25.174, \mathrm{p}<.001\right)$ with a mean rank writing score of 10.13 for monologic L2 group, 24.90 for dialogic L2 and 33.97 for dialogic L1 group. This finding shows that three instruction types for pre-writing stage have different effects to increase the writing performances of the students. When the mean ranks are considered, after the treatment, dialogic L1 group has the highest writing 
performance, and dialogic L2 and monologic L2 groups follow it. In other words, it was found out that the group who used their L1 during pre-writing stage with the help of DI had higher mean scores than the group who were instructed monologically and the group who were instructed through DI in the target language.

In order to see the difference between the control group who was taught monologically in L2 and one of the experimental groups who was instructed dialogically in L2, Mann-Whitney $U$ test was run on the writing scores of the participants to test whether the scores of two independent groups differ significantly. After a 5-week treatment, it was seen that there is a statistically significant difference between the writing performances of students who were instructed dialogically and monologically, $U=32, p=.001$. When the mean ranks were considered, the results indicated that the writing scores were greater for the dialogic L2 group than for the monologic L2 group, as can be seen in table 2. This finding shows that using DI techniques during the pre-writing stage of writing classes is effective to increase the writing performances of students.

Table 2. The results of Mann Whitney U test comparing post-test writing performances of monologic L2 and dialogic L2 groups

\begin{tabular}{lllllll}
\hline $\begin{array}{l}\text { Writing Post test } \\
\text { Mann Whitney }\end{array}$ & Group & $N$ & Mean Rank & $\begin{array}{l}\text { Sum } \\
\text { of Ranks }\end{array}$ & $U$ & $P$ \\
\hline & Dialogic L2 & 15 & 20.87 & 313.00 & 32.00 & .001 \\
& Monologic L2 & 15 & 10.13 & 152.00 & & \\
\hline
\end{tabular}

In addition, to find out the differences related to the L1 inclusion or exclusion between DI groups, another Mann Whitney test as indicated in table 6 was applied and the results showed that there is a statistically significant difference between the writing performances of dialogic L2 and dialogic L1 students, $\mathrm{U}=60.5, \mathrm{p}=.031$. The writing scores were greater for the dialogic L1 group than for the dialogic L2 group, as shown in table 3, when the mean ranks were analyzed.

Table 3. The results of Mann Whitney U test comparing post-test writing performances of dialogic L2 and dialogic L1 groups

\begin{tabular}{lllllll}
\hline $\begin{array}{l}\text { Writing Post test } \\
\text { Mann Whitney }\end{array}$ & Group & $N$ & Mean Rank & Sum of Ranks & $U$ & $P$ \\
\hline & Dialogic L1 & 15 & 18.97 & 284.50 & 60.50 & .031 \\
& Dialogic L2 & 15 & 12.03 & 180.50 & & \\
\hline
\end{tabular}

This finding shows that the inclusion of the mother tongue during the pre-writing stage of writing classes is effective to increase the writing performances of students.

\subsection{Qualitative results}

The content analysis of data conducted by means of semi-structured interviews revealed that under the main category of perceptions of students on L2 writing, such subcategories as reflection on L2 writing including the reasons of L2 writing need and 
impacts of L2 writing on students' beliefs; benefits of L2 writing tasks; idea generation process which indicated the main differences between MI in L2, DI, and DI with L1 use in warm-up stage emerged. The findings of the content analysis showed that students found L2 writing necessary for their future career and for their L2 language development in general. Accordingly, the results of the interviews revealed the fact that all of the participants in monologic L2, dialogic L2 and dialogic L1 groups have positive perceptions regarding their L2 writing and general language development with the reasons of feeling more self-confident in L2, being more motivated, willing to communicate and expressing oneself more actively as a result of five week writing courses. Furthermore, the participants emphasized the benefits of five week tasks for their language development including vocabulary, grammar, idea generation, and coherence and cohesion. Lastly, the main differences between three groups were revealed in idea generation process in relation to warm-up stages of the lessons. While the monologic L2 group relied on traditional methods for generating ideas including translation and keeping notes; most of the DI students highlighted that they made use of open discussions and talking with reasoning. Additionally, high number of students in DI L1 group mentioned the positive impact of L1 use for generating ideas in the warm up stage of the lesson.

\subsubsection{Reflection on L2 writing}

\subsubsection{Reasons of L2 writing need}

When the students were asked questions related to L2 writing to explore their feelings, attitudes and their ideas; it was found out that most of the students found L2 writing important for their future career (12/15) while only two of them focused on the significance of L2 writing for their L2 language development in general as indicated in the following quotes:

I think writing in English is an essential requirement for engineers as we need to communicate in English to work in international companies and interact with foreign customers, colleagues, and bosses. (S5)

I want to work in an international car company in production department, so I have to create engines and be involved in the production process. It means that the most important thing I need is writing in English to share my knowledge, ideas and write projects. (S9)

I will write codes in English and I want to be an academician. For these reasons, I have to write academic articles in L2. It is an obligation for me. (S1)

I strongly agree that if we develop our L2 writing skills, then we will have a chance to improve our English completely and our proficiency levels will be higher. (S3)

\subsubsection{Impacts of L2 writing on beliefs}

Accordingly, when the students were asked to reflect their ideas on whether fiveweek courses had any impact on their attitude toward writing skills and the reasons, all of the 15 students mentioned positive feelings and ideas regarding their L2 writing and general language development with the reasons of feeling more self-confident in 
L2 (7/15), being more motivated (4/15), willing to communicate (2/15), expressing oneself more actively (1/15) as evident in the following quotes:

Actually, I feel myself much more competent in writing a paragraph now. Because, in the previous years, we used to write about simple and boring topics specifically about daily routines, introducing ourselves, describing the famous people, etc. (S14)

I am really pleased with engaging in writing nowadays, as I feel myself developed in writing and vocabulary compared to the last weeks. I can organize my writing logically and I learned using transitions between ideas. (S8)

I am self-confident after 5 weeks. I think the writing tasks have a positive impact on idea generation and vocabulary and grammar knowledge as well. (S2)

\subsubsection{Benefits of L2 writing tasks}

When the students were asked whether they benefited from the tasks they have written for five weeks and the reasons, each of the participants mentioned the benefits in terms of language development including vocabulary (6/15), grammar $(5 / 15)$, idea generation $(2 / 15)$, coherence and cohesion $(2 / 15)$ in relation to five-week treatment as shown in the following quotes:

I improved my content specific vocabulary knowledge while writing the tasks. (S13)

I had a chance to form meaningful grammatical units and become more aware of rules, structures while forming sentences. (S7)

I became aware of the conjunctions to organize my ideas and the flow of the paragraph. (S11)

The best thing for me is creating more and more ideas and questioning my experiences before writing. For example, I generated many ideas related to my future job and realized the responsibilities I should have in this process. (S4)

\subsubsection{Idea generation process}

When the students' process of finding ideas to write the tasks were investigated, the dialogic L2 group and the dialogic L1 group students mentioned the effects of warm-up stages of the lesson to generate ideas necessary for writing. Most of these dialogic L2 instruction students highlighted that they made use of open discussions (3/15), while rest of them mentioned talking with reasoning (2/5) as shown in the following quotes:

I enjoyed the questioning of everything. For instance, when we say we want to be engineers, the teacher asked for a reason. When I gave a justification to help the society, she asked how I will achieve this and wanted me to clarify many issues on even a single topic. (S2)

Discussions with my classmates were helpful as I took notes and made use of them while writing. (S6)

On the other hand, except for one of the students, all of the dialogic L1 group of students (4/5) mentioned their positive beliefs regarding the L1 use in the warm-up stage of the lesson to describe the idea generation process as evident in the following quotes: 
Using our L1 while sharing our ideas and discussing the topic helped us a lot. Let's say, if I couldn't express my thoughts in Turkish, I may not achieve it in English and cannot participate in class discussions. (S8)

What I like most is that we had a discussion on the importance of honesty, telling white lies and expressed us how acceptable they could be. It facilitated my writing and made it easier to express myself both orally and on paper. (S13)

I think we should think and create ideas in L2 to be able to write in L2. If one feels the obligation of using L2 then s/he can be successful, if not, s/he will never feel the necessity of using the target language. (S1)

However, most of the monologic L2 instruction group students generally mentioned more traditional methods including translation from L1 (3/5) while the rest of them mentioned keeping notes and making lists (2/5) considering the idea generation process regarding L2 writing as indicated in the following quotes:

Before writing, I wrote my ideas in Turkish and then, I tried to translate them into English with the help of the online dictionaries. (S6)

I expressed my ideas and made a list to make use of them while writing. Actually, it helped me a lot. (S12)

What's more, four of the monologic L2 instruction group students mentioned that idea generation is the biggest challenge they faced in L2 writing while one of them stated that he didn't have any difficulty in generating ideas as shown in the following quotes:

It was highly hard for me to generate ideas as it was same in Turkish, too. I cannot make up make mind how I should start and what I can write. (S5)

I think generating ideas is the most enjoyable part as you feel yourself into writing process and the theme. (S3)

In the light of these findings, it is clear that all of the participants in monologic L2, dialogic L2 and dialogic L1 groups have positive perceptions regarding their L2 writing and general language development at the end of five week courses. In this vein, the participants pointed out the benefits of five week tasks for their language development including vocabulary, grammar, idea generation, coherence and cohesion. On the other hand, the main differences between three groups emerged during the idea generation process of the warm-up stages of the lessons. While majority of students in DI L1 group mentioned the positive impact of L1 use for generating ideas in the warm up stage of the lesson, the monologic L2 group mentioned traditional methods for generating ideas including translation and keeping notes. However, most of these DI students emphasized the benefits of the open discussions and talking with reasoning for generating ideas.

\section{Discussion and Conclusion}


The present research aimed to explore and compare the effects of monologic instruction and DI as well as DI in L1 and L2 on students' writing performance in relation to the pre-writing stage of the writing process. The objective of this research was to find out the ways that enable and trigger students' thinking skills and idea generation process in L2 while producing a price of written work on a certain topic. Additionally, this research aimed to examine learners' perceptions and beliefs related to L2 writing in general, DI and L1 vs. L2 use in writing classes. To this end, an experimental study was conducted in three classes and different methods as well as mediums were employed to reveal the best method to encourage student thinking time and producing skills. Also, interviews were conducted with the learners to investigate their perceptions.

Quantitative findings of the study which were found out through the medium of pre-and post-writing tasks indicated that the group instructed through dialogic L1 had the highest scores for five weeks during the research process compared to monologic L2 and dialogic L2 groups' writing performances. Additionally, pairwise comparisons between monologic L2 and dialogic L2 groups disclosed that the writing scores were greater for the dialogic L2 group than for the monologic L2 group. These findings were in accordance with the earlier research by Lee (2016) who pointed out that monologic classroom discourse hindered the collaborative understanding and the chances of creating knowledge by teachers and students and that dialogic interactions enhanced the learning opportunities of students. Equivalently, Gillies (2015) reported that teachers who employed DI were able to stimulate their students' thinking, enabling them to answer by reflecting, assisting students to build bridges between their previous knowledge and the upcoming data. Similar to the findings of the present study, Zwiers and Crawford (2011) suggested that dialogic talk which enabled a more profound phase of thinking helped learners arrange and systematize their ideas in writing. Furthermore, the findings of the comparisons between dialogic L1 and dialogic L2 groups' writing performances revealed that the scores of the students who were instructed through dialogic L1 were higher in comparison to performances of the students who were in the dialogic L2 group. This result was similar to those of a number of studies (Atkinson, 1987; Bruen \& Kelly, 2017; de la Colina \& Mayo, 2009; Nation, 2003; Storch \& Wigglesworth, 2003) in the literature in the same degree. In the same manner, Cook (2001) mentioned that the conscientious and righteous inclusion of L1 enhanced the efficiency and learning. Some studies (Cumming, 1989, 1990) also indicated that writing was bilingual and that learners already possessed the knowledge of their mother tongue before they started to learn a foreign language.

The qualitative findings of the study obtained by means of the semi-structured indepth interviews which aimed to find out the perceptions of students' toward L2 writing by elaborating on their beliefs, feelings, and experiences through monologic L2, dialogic L2, and dialogic L1 instruction, supported the findings of the reviewed literature. For instance, the participating students asserted positive attitudes towards the use of L1 in the warm-up stage of the lesson to generate ideas, organize their thoughts and plan their writing process. In accordance with what Cumming (1987) 
revealed, learners benefited from their L1 to create ideas and to control their written product. In the same vein, L1 was claimed to be an effectively used tool in the prewriting stages of the writing process as supported by Akyel (1994) who found out the positive effects of L1 use in L2 writing in terms of supporting the learners to create and plan their opinions in their L1 and L2. In parallel with the findings of this previous study, Kim (2010) also revealed that the students benefited from translating their own written work and emphasized the positive impact of L1 use as a supportive mechanism for increasing writing performance. In that sense, in this study, the participating students in the dialogic L1 group specifically figured out the positive effects of using L1 in idea generation process in relation to the warm-up stages of the lesson. Furthermore, even the monologic L2 students also relied on translation strategies from their L1 while trying to create ideas appropriate for their writing tasks.

Another result of the study which was in accordance with the findings of the previous studies was related to DI in L2 which was implemented in the warm-up stage of the writing process of the students. In this context, the participants in this study had positive perceptions towards the DI activities particularly in the pre-stage including discussions, student talk with reasoning and interactions with their peers. This finding supported the previous research conducted by Choi, Tatar, and Kim (2014) who claimed the importance of dialogic interactions in improving L2 students' construction of new ideas depending on their background knowledge. In addition, as suggested by Alexander (2013), DI is a medium for broadening learners' reasoning skills and propelling their learning. In the light of the findings of this study, DI both in L2 and L1 was found out to be an effective tool for improving students' thinking skills, enhancing their idea generation strategies, raising background knowledge on a topic, and as a result, supporting student' L2 writing performances.

Furthermore, the results of the study which indicated that the majority of the EFL learners have positive beliefs in relation to L2 writing also supported the reviewed literature. For instance, as suggested by Ismail (2011), the students had high perceptions about the importance of ESL writing skill for their academic study and their future career. In line with this, the findings of the content analysis in this study showed that the students found L2 writing necessary for their future career and for their L2 language development in general. This result indicated that EFL students were aware of their needs to improve their writing proficiency in English. This result was also in accordance with another study conducted by Mazdayasna and Tahririan (2008) about the EFL needs of Iranian undergraduate students and revealed that the L2 students were aware of their needs and the requirements to improve their general language proficiency for writing performances.

The strength of the present study arose from the gap it aimed to fill in the literature suggesting a new understanding of DI with an integration of the mother tongue of students by enabling them to think systematically and critically in the process of pre-writing stage of the writing lesson. Although a number of studies mentioned in the previous sections examined the DI and L1 use on their own 
separately, this study, with a more elaborate manner, aimed to define the interaction roles of the teachers and students and suggested a medium of instruction, which was the mother tongue of the students.

As for the limitations of the present study, sample size would be larger with multiple cases and the implementation period would be longer to examine the longterm objectives of the DI in L1 and in L2 on students' L2 writing performances in further research. Furthermore, further studies could investigate the whole process of writing as this study was restricted to the warm-up stages of the writing process.

\section{References}

Abdel Latif, M. M. (2007). The factors accounting for the Egyptian EFL university students' negative writing affect. Essex Graduate Student Papers in Language and Linguistics, 9(1), 57-82.

Akyel, A. (1994). First language use in EFL writing: Planning in Turkish vs. planning in English. International Journal of Applied Linguistics, 4(2), 169-196. https://doi.org/10.1111/j.1473-4192.1994.tb00062.x

Alexander, R. (2008). Culture, dialogue and learning: notes on an emerging pedagogy. In N. Mercer \& S. Hodgkinson (Eds.), Exploring talk in school: Inspired by the work of Douglas Barnes (pp. 91-114). London: SAGE Publications.

Alexander, R. (2013). Essays on pedagogy. New York: Routledge.

Alexander, R. J. (2006). Towards dialogic teaching: Rethinking classroom talk. Cambridge: Dialogos.

Altınyelken, K. H. (2011). Student- centred pedagogy in Turkey: Conceptualisations, interpretations and practices. Journal of Education Policy, 26(2), 137-160. https://doi.org/10.1080/02680939.2010.504886

Atkinson, D. (1987). The mother tongue in the classroom: A neglected resource? ELT Journal, 41(4), 241-247. https://doi.org/10.1093/elt/41.4.241

Auman, M. E. (1999). Step up to writing. Longmont, CO: Sopris West Publishing.

Bakhtin, M. M. (1984). Problems of Dostoevsky's poetics (Vol. 8). Minneapolis, MN: University of Minnesota.

Beare, S. (2000). Differences in content generating and planning process of adult L1 and L2 proficient writers (Unpublished doctoral dissertation). University of Ottawa, Ottawa, Ontario.

Becker, C. (1991). Quality and quantity of writing German in early acquisition: A case for associative activities in foreign language courses. (Unpublished doctoral dissertation). Louisiana State University, Baton Rouge.

Bereiter, C., \& Scardamalia, M. (1987). An attainable version of high literacy: Approaches to teaching higher-order skills in reading and writing. Curriculum Inquiry, 17(1), 9-30. https://doi.org/10.2307/1179375

Bruen, J., \& Kelly, N. (2017). Using a shared L1 to reduce cognitive overload and anxiety levels in the L2 classroom. The Language Learning Journal, 45(3), 368-381. https://doi.org/10.1080/09571736.2014.908405

Burbules, N. C. (1993). Dialogue in teaching: Theory and practice. New York: Teachers College Press. 
Burns, C., \& Myhill, D. (2004). Interactive or inactive? A consideration of the nature of interaction in whole class teaching. Cambridge Journal of Education, 34(1), 35-49. https://doi.org/10.1080/0305764042000183115

Byrd, R. D. (2011). Putting the writing process into action in the L2 classroom: Pre-writing techniques that work. The Journal of Language Teaching and Learning, 1(1), 64-77.

Byrnes, H., \& Manchón, R. M. (2014). Insights from and for L2 writing: An introduction. In H. Byrnes \& R. M. Manchón (Eds.), Task-based language learning: Insights from and for L2 writing (pp. 1-23). Amsterdam, Netherlands: John Benjamins.

Caccamise, D. J. (1987). Idea generation in writing. In A. Matsuhashi (Ed.), Writing in real time: Modeling production processes (pp. 224-253). Norwood, NJ: Ablex.

Carrell, P.L., \& Eisterhold, J.C. (1983). Schema theory and ESL reading pedagogy. TESOL Quarterly, 17(1), 553-573. https://doi.org/10.2307/3586613

Choi, J., Tatar, B., \& Kim, J. (2014). Dialogic interactions in the English-mediated classroom: A case study of a social science class for engineering students in Korea. Asian Social Science, 10(16), 123-130. https://doi.org/10.5539/ass.v10n16p123

Cohen, A. D., \& Brooks-Carson, A. (2001). Research on direct versus translated writing: Students' strategies and their results. The Modern Language Journal, 85(2), 169-188. https://doi.org/10.1111/0026-7902.00103

Cook, V. (2001). Using the first language in the classroom. Canadian Modern Language Review, 57(3), 402-423. https://doi.org/10.3138/cmlr.57.3.402

Cumming, A. (1987, April). Decision Making and Text Representation in ESL Writing Performance. Paper presented at the 2lst Annual TESOL Convention, Miami Beach, Florida, USA.

Cumming, A. (1989). Writing expertise and second language proficiency. Language Learning, 39(1), 81-135. https://doi.org/10.1111/j.1467-1770.1989.tb00592.x

Cumming, A. (1990). Metalinguistic and ideational thinking in second language composing. Written Communication, 7(1), 482-511. https://doi.org/10.1177/0741088390007004003

De la Colina, A. A., \& Mayo, M. D. P. G. (2009). Oral interaction in task-based EFL learning: The use of the L1 as a cognitive tool. IRAL-International Review of Applied Linguistics in Language Teaching, 47(3-4), 325-345.

Edelsky, C. (1982). Writing in a bilingual program: The relation of L1 and L2 texts. TESOL Quarterly, 16(2), 211-228. https://doi.org/10.2307/3586793

Freeman, D., \& Freeman, Y. (2001). Between worlds: Access to second language acquisition. 2nd ed. Portsmouth, NH: Heinemann.

Friedlander, A. (1990). Composing in English: Effects of a first language on writing in English as a second language. In B. Kroll. (Ed.), Second language writing: Research insights for the classroom (pp. 109-125). Cambridge: Cambridge University Press.

Galton, M. J. (2007). Learning and teaching in the primary classroom. London: Sage.

Ghavamnia, M., Tavakoli, M., \& Esteki, M. (2013). The effect of pre-task and online planning conditions on complexity, accuracy, and fluency on EFL learners' written production. Porta Linguarum, 20(1), 31-43.

Gillies, R. M. (2016). Dialogic interactions in the cooperative classroom. International Journal of Educational Research, 76(1), 178-189. https://doi.org/10.1016/j.ijer.2015.02.009

Gillies, R. M. (2015).Teacher dialogue that supports collaborative learning in the classroom. In L. B. Resnick, C. S. C. Asterhan \& S. N. Clarke (Eds.), Socializing intelligence through academic talk and dialogue (pp. 335-345). Washington DC, United States: American Educational Research Association. 
Graham, S., \& Perin, D. (2007). Writing next: Effective strategies to improve writing of adolescents in middle and high schools - A report to Carnegie Corporation of New York. Washington, DC: Alliance for Excellent Education.

Gregory, M. (2007). A framework for facilitating classroom dialogue. Teaching Philosophy, 30(1), 59-84. https://doi.org/10.5840/teachphil200730141

Hajhosseiny, M. (2012). The Effect of dialogic teaching on students' critical thinking disposition, Procedia - Social and Behavioral Sciences, 69(1), 1358-1368. https://doi.org/10.1016/j.sbspro.2012.12.073

Han, Y., \& Hyland, F. (2015). Exploring learner engagement with written corrective in a Chinese tertiary EFL classroom. Journal of Second Language Writing, 30(1), 31-44. https://doi.org/10.1016/j.jslw.2015.08.002

Hatipoğlu-Kavanoz, S. (2006). An exploratory study of English language teachers' beliefs, assumptions, and knowledge about learner-centeredness. TOJET, 5(2), 3-9.

Hornung, A. (2000). Method awareness and the teaching of writing. In G. Bäuer (Ed.), Writing Across Languages (pp. 131-140). Stamford, CT: Ablex Publishing Corporation.

Hyland, K. (2003). Second language writing. New York, Cambridge University Press.

Hyland, K., \& Hyland, F. (2006). Feedback on second language students' writing. Language Teaching, 39(1), 83-101. https://doi.org/10.1017/S0261444806003399

Ismail, S. A. A. (2011). Exploring students' perceptions of ESL writing. English Language Teaching. Canadian Center of Science and Education, 4(2), 73-83.

Jordan, R. R. (1997). English for academic purposes: A guide and resource book for teachers. Cambridge University Press.

Kellogg, R. T. (1996). A model of working memory in writing. In C. M. Levy \& S. Ransdell (Eds.), The science of writing: Theories, methods, individual differences, and applications (pp. 57-71). Hillsdale, NJ, US: Lawrence Erlbaum Associates, Inc.

Kellogg, R. T. (1988). Attentional overload and writing performance: Effects of rough draft and outline strategies. Journal of Experimental Psychology: Learning, Memory, and Cognition, 14(2), 355-365. https://doi.org/10.1037/0278-7393.14.2.355

Kim, E. Y. (2010). Using translation exercises in the communicative EFL writing classroom. ELT Journal, 65(2), 154-160.

Knutson, E. M. (2006). Thinking in English, writing in French. The French Review, 80(1), 88109.

Kramsch, C. (1993). Context and culture in language teaching. New York: Oxford University Press.

Krapels, A. (1990). An overview of second language writing process research. In B. Kroll (Ed.), Second language writing: Research insights for the classroom (pp. 37-56). New York: Cambridge University Press.

Kroll, B. M. (1990). Second language writing: Research insights for the classroom. Cambridge: Cambridge University Press.

Kumpulainen, K., \& Lipponen, L. (2010). Productive interaction as agentic participation in dialogic enquiry. In K. Littleton \& C. Howe (Eds.), Educational dialogues: Understanding and promoting productive interaction (pp. 48-63). London: Routledge.

Kurt, G., \& Atay, D. (2007). The effects of peer feedback on the writing anxiety of prospective Turkish teachers of EFL. Journal of Theory and Practice in Education, 3(1), 12-23.

Lay, N. (1982). Composing processed of adult ESL learners: A case study. TESOL Quarterly, 16(1), 406-407.

Lee, R. (2016). Implementing dialogic teaching in a Singapore English language classroom. RELC Journal, 47(3), 279-293. https://doi.org/10.1177/0033688216631171 
Levy, C. M., \& Ransdell, S. (1995). Is writing as difficult as it seems? Memory \& Cognition, 23(6), 767-779.

Mahn, H. (2008). A dialogic approach to teaching L2 writing, In J.P. Lantolf \& M.E. Poehner (Eds.), Sociocultural theory and the teaching of second languages (pp. 115-138). London: Equinox.

Martinez-Gibson, E. (1998). A study on cultural awareness through commercials and writing. Foreign Language Annals, 31(1), 115-139. https://doi.org/10.1111/j.19449720.1998.tb01337.x

Mazdayasna, G., \& Tahririan, M. (2008). Developing a profile of the ESP needs of Iranian students: The case of students of nursing and midwifery. Journal of English for Academic Purposes, 7(4), 277-289. https://doi.org/10.1016/j.jeap.2008.10.008

Mercer, N., Dawes, L., \& Staarman, J. K. (2009) Dialogic teaching in the primary science classroom. Language and Education, 23(4), 353-369. https://doi.org/10.1080/09500780902954273

Mercer, N., \& Dawes, L. (2014). The study of talk between teachers and students, from the 1970s until the 2010s. Oxford Review of Education, 40(4), 430-445. https://doi.org/10.1080/03054985.2014.934087

Mercer, N., \& Littleton, K. (2007). Dialogue and the development of children's thinking: A socio-cultural approach. London: Routledge.

Miles, M. B. \& Huberman, A. M. (1994). Qualitative data analysis. Thousand Oaks, CA: Sage.

Motlhaka, H. A., \& Makalela, L. (2016). Translanguaging in an academic writing class: Implications for a dialogic pedagogy. Southern African Linguistics and Applied Language Studies, 34(3), 251-260. https://doi.org/10.2989/16073614.2016.1250356

Murphy, P. K., Wilkinson, I. A., Soter, A. O., Hennessey, M. N., \& Alexander, J. F. (2009). Examining the effects of classroom discussion on students' comprehension of text: A metaanalysis. Journal of Educational Psychology, 101(3), 740-764. https://doi.org/10.1037/a0015576

Nation, P. (2003). The role of the first language in foreign language learning. Asian EFL Journal, 5(2), 1-8.

Novak, J.D. (1998). Learning, creating, and using knowledge: Concept maps as facilitative tools in schools and corporations. Mahwah, NJ: Lawrence Erlbaum Associates, Inc.

Ojima, M. (2006). Concept mapping as pre-task planning: A case study of three Japanese ESL writers. System, 34(4), 566-585. https://doi.org/10.1016/j.system.2006.08.003

Ortega, L. (2012). Epilogue: Exploring L2 writing-SLA interfaces. Journal of Second Language Writing, 21(4), 404-415. https://doi.org/10.1016/j.jslw.2012.09.002

Otten, S., Engledowl, C., \& Spain, V. (2015). Univocal and dialogic discourse in secondary mathematics classrooms: The case of attending to precision. ZDM, 47(7), 1285-1298.

Parker, M., \& Hurry, J. (2007). Teachers' use of questioning and modelling comprehension skills in primary classrooms. Educational Review, 59(3), 299-314. https://doi.org/10.1080/00131910701427298

Peel, A. (2014). Writing between the lines: Aaliyah's dialogic strategies for overcoming academic writing disengagement. Journal of Language and Literacy Education, 10(1), 6581.

Pimentel, D. S., \& McNeill, K. L. (2013). Conducting talk in secondary science classrooms: Investigating instruction moves and teachers' beliefs. Science Education, 97(3), 367-394. https://doi.org/10.1002/sce.21061

Rau, P.S., \& Sebrechts, M.M. (1996). How initial plans mediate the expansion and resolution of options in writing. The Quarterly Journal of Experimental Psychology. 49A, 616-638. 
Reznitskaya, A., Kuo, L., Clark, A., Miller, B., Jadallah, M., Anderson, R.C., \& Nguyen-Jahiel, K. (2009). Collaborative reasoning: A dialogic approach to group discussions. Cambridge Journal of Education, 39(1), 29-48. https://doi.org/10.1080/03057640802701952

Ruddell, R. B., \& Boyle, O. F. (1989). A study of cognitive mapping as a means to improve summarization and comprehension of expository text. Literacy Research and Instruction, 29(1), 12-22. https://doi.org/10.1080/19388078909557992

Sağlam, G. (1993). The attitudes of some Turkish students toward responses to their EFL writing. (Unpublished master's thesis). The Institute of Economic and Social Science of Bilkent University, Ankara, Turkey.

Schwarz, B. B., Neuman, Y., \& Biezuner, S. (2000). Two wrongs may make a right... if they argue together! Cognition and Instruction, 18(4), 461-494. https://doi.org/10.1207/S1532690XCI1804_2

Scott, M. (1996). Wordsmith tools. Oxford: Oxford University Press.

Scott, P. H., Mortimer, E. F. \& Aguiar, O. G. (2006). The tension between authoritative and dialogic discourse: A fundamental characteristic of meaning making interactions in high school science lessons. Science Education, 90(4), 605-631.

Sebranek, P., Meyer, V., \& Kemper, D. (2000). Write source 2000: A guide to writing, thinking, and learning. Wilmington, MA: Write Source/Great Source Education Group.

Sedova, K., Sedlacek, M., \& Svaricek, R. (2016). Teacher professional development as a means of transforming student classroom talk. Teaching and Teacher Education, 57(1), 14-25. https://doi.org/10.1016/j.tate.2016.03.005

Sevgi, E. (2016). A comparison of the cognitive processes involved in L2 learners' writing process when they are composing in English and in their L1. Procedia-Social and Behavioral Sciences, 232(1), 346-353. https://doi.org/10.1016/j.sbspro.2016.10.047

Smart, J. B. \& Marshall, J. C. (2013). Interactions between classroom discourse, teacher questioning, and student cognitive engagement in middle school science. Journal of Science Teacher Education, 24(2), 249-267.

Splitter, L. J., \& Sharp, A. M. (1995). Teaching better thinking: The classroom community of inquiry. Melbourne: Australian Centre for Educational Research.

Steward, T. T., \& McClure, G. (2013). Freire, Bakhtin, and collaborative pedagogy: A dialogue with students and mentors. International Journal for Dialogical Science, 7(1), 91-108.

Storch, N., \& Wigglesworth, G. (2003). Is there a role for the use of the L1 in an L2 setting? TESOL Quarterly, 37(4), 760-770. https://doi.org/10.2307/3588224

Strasma, K., \& Foster, G. (1992). Collaboration within writing classes: An ethnographic point of view. The Writing Instructor, Spring/Summer, 111-127.

Swaffar, J. K. (1988). Readers, texts, and second languages: The interactive process. Modern Language Journal, 72(1), 123-145.

Teo, P. (2016). Exploring the dialogic space in teaching: A study of teacher talk in the preuniversity classroom in Singapore. Teaching and Teacher Education, 56(1), 47-60. https://doi.org/10.1016/j.tate.2016.01.019

Urzua, C. (1987). You stopped too soon: Second language children composing and revising. TESOL Quarterly, 21(1), 279-304.

Vacca, R. T., Vacca, J. L., \& Mraz, M. E. (2010). Content area reading: Literacy and learning across the curriculum (10th ed.). Boston: Allyn and Bacon.

Wang, L. (2003). Switching to first language among writers with differing second-language proficiency. Journal of Second Language Writing, 12(4), 347-375. https://doi.org/10.1016/j.jslw.2003.08.003 
Wang, W., \& Wen, Q. (2002). L1 use in the L2 composing process: An exploratory study of 16 Chinese EFL writers. Journal of Second Language Writing, 11(3), 225-246. https://doi.org/10.1016/S1060-3743(02)00084-X

Webb, N., Franke, M., Ing, M., Wong, J., Fernandez, C., Shin, N., \& Turrou, A.C. (2014). Engaging with others' mathematical ideas: Interrelationships among student participation, teachers' instructional practices, and learning. International Journal of Educational Research, 63(1), 79-93. https://doi.org/10.1016/j.ijer.2013.02.001

Wegerif, R., Mercer, N., \& Dawes, L. (1999). From social interaction to individual reasoning: An empirical investigation of a possible socio-cultural model of cognitive development. Learning and Instruction, 9(6), 493-516. https://doi.org/10.1016/S0959-4752(99)00013-4

Wells, G. (2000). Dialogic inquiry in education: Building on the legacy of Vygotsky. In C. D. Lee \& P. Smagorinsky (Eds.), Vygotskian perspectives on literacy research (pp. 51-85). New York, NY: Cambridge University Press.

Whalen, K., \& Menard, N. (1995). L1 and L2 writers' strategic and linguistic knowledge: A model of multiple-level discourse processing. Language Learning, 45(3), 381-418. https://doi.org/10.1111/j.1467-1770.1995.tb00447.x

Williams, J. D. (2005). Preparing to teach writing: Research, theory, and practice (3rd ed.). Mahwah, NJ: Lawrence Erlbaum.

Woodall, B. R. (2002). Language-switching: Using the first language while writing in a second language. Journal of Second Language Writing, 11(1), 7-28. http://dx.doi.org/10.1016/S1060-3743(01)00051-0

Zwiers, J., \& Crawford, M. (2011). Academic conversations: Classroom talk that fosters critical thinking and content understandings. Portland, Me.: Stenhouse.

\section{Appendix A. Components of dialogic instruction in L2 and in-class examples}

A.1. Read each situation. Imagine you are in the situation and choose your answer. Then discuss your choice with your partner.

Situation 1: Your grandmother gives you a watch. You don't like it. What do you say?

Grandmother: "I got this for you."

You: "Thank you. I really like it." OR “Thank you. It's not really my style, though.”

Situation 2: A classmate asks you to go ice-skating. You don't want to. What do you say?

Grandmother: "Do you want to go ice-skating tomorrow?"

You: "I'm sorry. I can't go. I'm busy tomorrow." OR "No thanks. I don't really want to go."

A.2. Read each statement in the survey. Check Agree or Disagree. Compare your answers in a group via giving justifications. 
TELL the TRUTH!!!

1. It's possible to tell the truth all of the time.

2. People do not want to hear the truth.

3. A good friend always tells the truth.

4. Some lies are OK because they make people happy.

5. All lies are wrong.

\section{Appendix B. Semi-structured interview questions in English}

1. What do you think about L2 writing? Do you think it is important? If yes, in what ways it is important? If not, why?

2. Do you prefer pre-writing activities in L1 or L2? Why? (talking with reasoning, teacher's open ended questions, teacher uptake and open discussions)

3. Did you enjoy warm up stages of the writing process? If so, why? If not, why?

4. Did you benefit from the tasks you have written for five weeks? If so, what were the benefits? If not, why not?

5. Did these five week course have a positive impact on your attitude toward writing skills? If so, why? If not, why?

6. How did you find ideas to write? What kind of a process was it?

7. Describe the challenges you faced before and while writing that you experienced.

8. How did you find the five week writing lessons compared to the previous ones? What were the differences you experienced?

\section{Copyrights}

Copyright for this article is retained by the author(s), with first publication rights granted to the Journal.

This is an open-access article distributed under the terms and conditions of the Creative Commons Attribution license (CC BY-NC-ND) (http://creativecommons.org/licenses/by-nc-nd/4.0/). 